\title{
HYPHAL-LIKE EXTENSION AND PSEUDOHYPHAL FORMATION IN INDUSTRIAL STRAINS OF YEASTS INDUCED BY ISOAMYL ALCOHOL
}

\author{
Sandra Regina Ceccato-Antonini*; Paula Cristina da Silva
}

Departamento de Tecnologia Agroindustrial e Sócio-Economia Rural, Centro de Ciências Agrárias, Universidade Federal de São

Carlos, Araras, SP, Brasil

Submitted: September 09, 2001; Returned to authors for corrections: April 04, 2002; Approved: September 24, 2002

\section{SHORT COMMUNICATION}

\begin{abstract}
Yeasts can produce pseudohyphae and hyphal-like extensions under certain growth conditions like isoamyl alcohol (IAA) induction, a chief constituent of fusel oil, which is a subproduct from the ethanolic fermentation. The morphology switch from yeast to a filamentous form can be troublesome to the process. In this work it was studied the influence of fusel alcohols, nitrogen sources (ammonium sulphate and leucine) and glifosate (a chemical maturator for sugar cane) added to a complex medium on some industrial strains of yeasts isolated from the fermentative process. Two industrial strains showed transition to hyphal-like extensions or pseudohyphae (clusters of cells) upon addition of IAA from 0.3 to $0.9 \% / \mathrm{v}$. The alterations were reversible when the yeasts were reinoculated in YEPD without IAA. Although pseudohyphae are a result of nitrogenlimited medium, we observed them as a result of IAA addition. No influence of the nitrogen source or isopropilic alcohol or glifosate was detected for any strain studied in the concentrations used.
\end{abstract}

Key words: isoamyl alcohol, ethanol, yeast, pseudohyphae, hyphal-like extension

According to Dickinson (2), pseudohyphae are defined as chains of regular-shaped, elongated cells in which polar budding predominates. A hyphal-like extension is taken to mean a structure originating from a bud which has undergone abnormal length extension so as to exceed the length of the mother cell from which it arose, but without the isotropic swelling characteristic of the normal yeast cell cycle. In the past 10 years, the development of pseudohyphae in Saccharomyces cerevisiae and other yeasts has received considerable attention $(2,3,4,6,7,9,12,14)$.

Many factors can be attributed to the switch from the yeast to the filamentous form: nitrogen starvation (6); oxygen limitation $(7,14)$ and 'fusel' alcohols $(2,9)$. 'Fusel' oil is used to refer to the mixture of compounds which remains after most of the ethanol has been removed from the yeast fermentation. The chief constituents of 'fusel' oil are isoamyl alcohol - IAA and n-amyl alcohol (around 55.3\%). They are major products of branchedchain amino acid catabolism (13).

The yeast filamentous morphology can be troublesome to the fermentative process like formation of a 'foam' (yeast cell concentration), gas jailing into the tanks, sugar cane juice flowing out the tanks, with sugar and alcohol loss (1).

Since some cases of this morphology switch were observed in some distilleries (1), it was proposed to study in vitro the influence of 'fusel' alcohols (IAA and isopropilic alcohol IPA), nitrogen sources and glifosate (a chemical maturator used commonly for sugar cane) on the morphology of industrial Sacch. cerevisiae strains (CCA 037, CCA 038, CCA 361 and CCA 567) and laboratory yeast strains (CCA 003 Sacch. cerevisiae NCYC 1006; CCA 004 - Sacch. cerevisiae NCYC 738; CCA 118 - Sacch. cerevisiae NCYC 232 and baking yeast), from the Universidade Federal de São Carlos - Centro

\footnotetext{
* Corresponding author. Mailing address: Universidade Federal de São Carlos, Centro de Ciências Agrárias, Departamento de Tecnologia Agroindustrial
} e Sócio-Economia Rural. Caixa Postal 153. 13600- 970, Araras, SP, Brasil. Tel.: (+5519) 542-4006. Fax: (+5519) 542-3800. E-mail: antonini@cca.ufscar.br 
de Ciências Agrárias culture collection. All strains showed unicellular morphology but strain CCA 038, showed clusters of cells.

All the yeast strains were cultured at $30^{\circ} \mathrm{C}$ for $48 \mathrm{~h}$ in YEPD complex medium ( $1 \%$ yeast extract, $1 \%$ peptone, $2 \%$ glucose, $2 \%$ agar), to which IAA or IPA ( 0.1 to $1.0 \% \mathrm{v} / \mathrm{v})$, or glifosate (1 to $50 \mathrm{ppm}$ ) were added. The inoculum was $10^{3}$ cells $/ \mathrm{mL}$, prepared in saline solution being spread $0.1 \mathrm{~mL}$ onto the medium surface
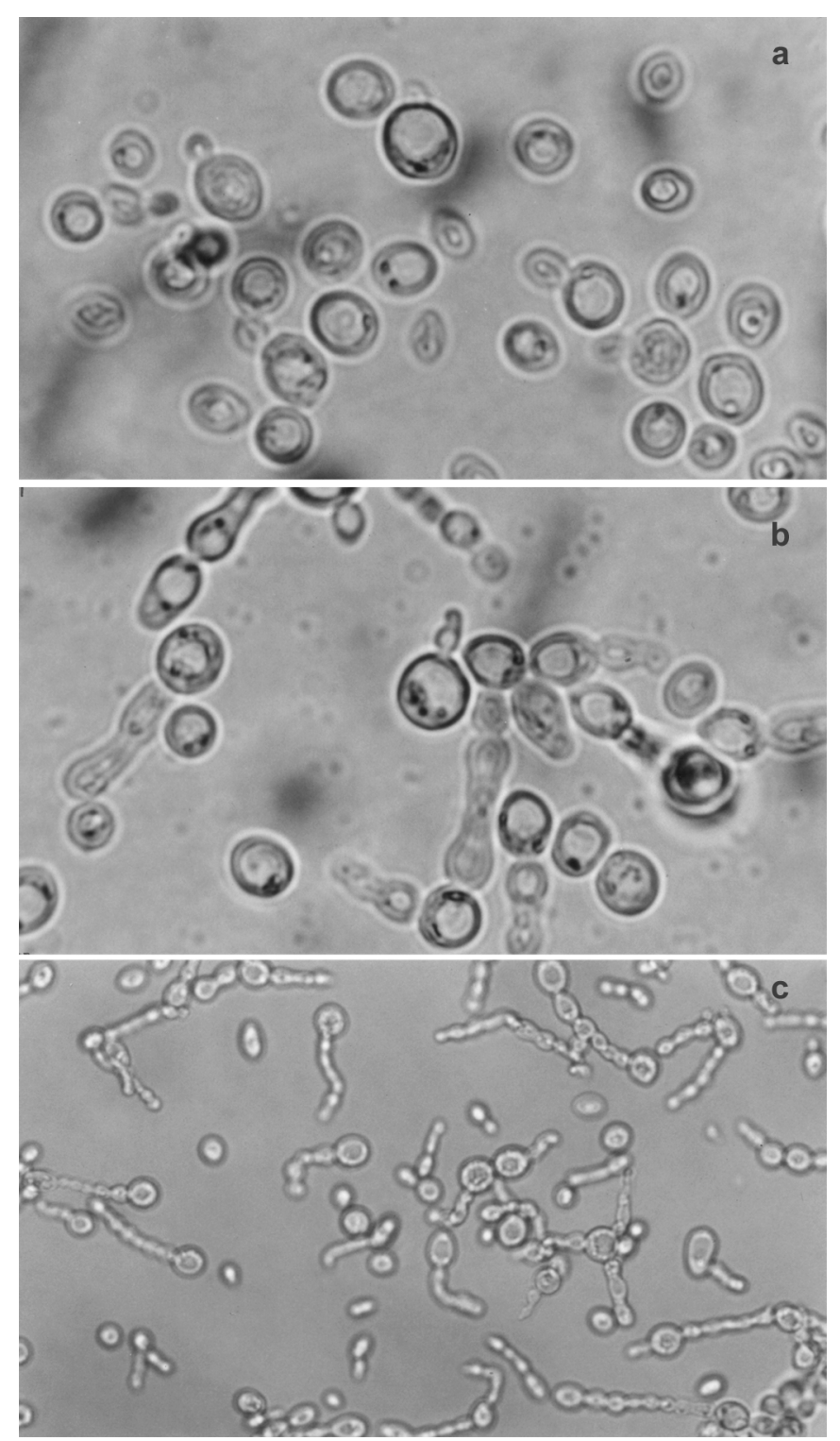

Figure 1. Formation of hyphal-like extensions by the industrial strain CCA 037. (a) Cells cultured in YEPD medium, 1000X magnification; (b) Cells cultured in YEPD containing $0.6 \%(\mathrm{v} / \mathrm{v})$ isoamyl alcohol, 400X magnification; (c) Cells cultured in YEPD containing $0.8 \%$ (v/v) isoamyl alcohol, $1000 \mathrm{X}$ magnification. in Petri dishes. Ammonium sulphate and leucine were used as nitrogen sources in minimal medium $(0.67 \%$ Yeast Nitrogen Base, $2 \%$ agar) in the concentrations of 0.1 and $0.01 \%$, separately or in combination of both. Macro and microscopical observations were made under optical microscope to verify the appearance of hyphal structures or cluster of cells. A hundred of cells or structures were counted in a microscope field discriminating between normal cells (unicellular form) or altered cells (pseudohyphae or cluster of cells). When cell alteration was detected, the yeast was transferred to YEPD without addition of chemicals to observe the reversion to the unicellular form. All the trials were repeated twice.

No morphological changes were observed in any yeast when the experiments with glifosate, IPA and different nitrogen sources were analysed. Only the yeasts CCA 037 and CCA 567 showed morphology switch from yeast to filamentous form when IAA was used. For CCA 037, hyphal-like extensions were observed in medium with 0.3 to $0.9 \%$ of IAA (Fig. 1), reaching $14 \%$ of the total cells at $0.5 \%$-IAA (Table 1 ). Clusters of cells (pseudohyphae) were detected in the CCA 567 strain (Fig. 2).

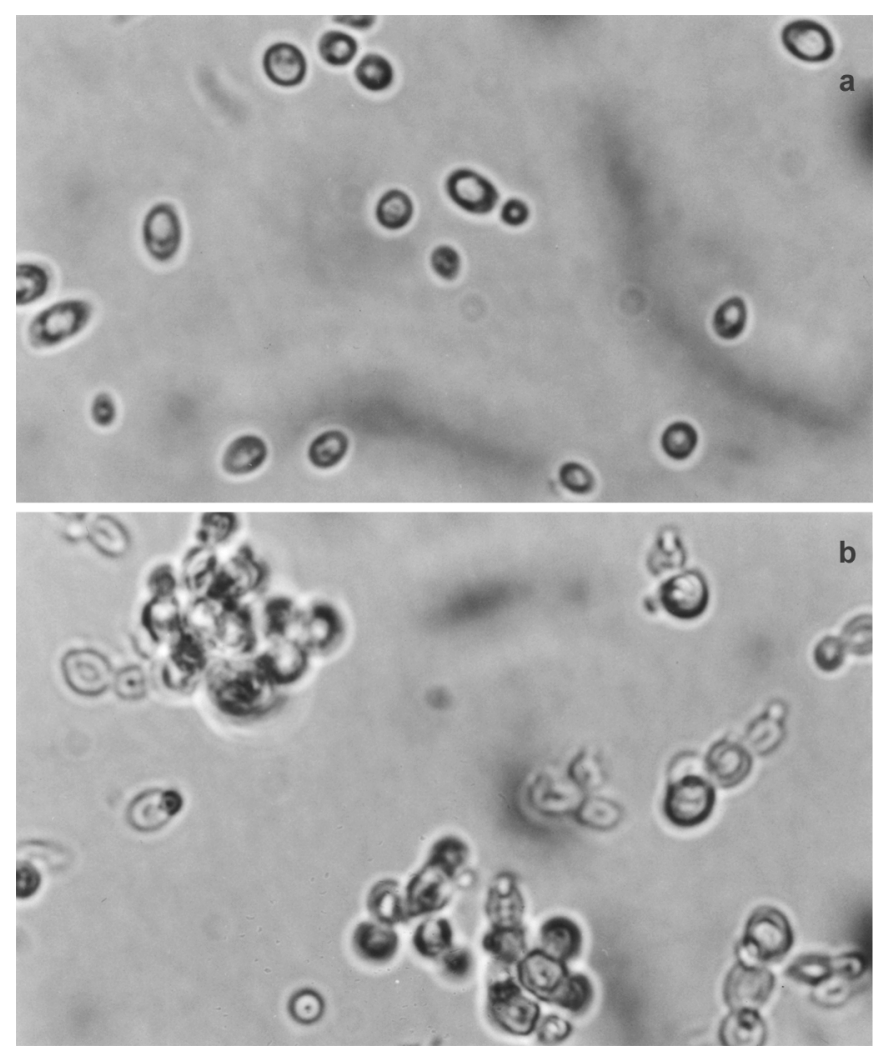

Figure 2. Formation of pseudohyphae by the industrial strain CCA 567. (a) Cells cultured in YEPD medium, 1000X magnification; (b) Cells cultured in YEPD containing $0.8 \%$ (v/v) isoamyl alcohol, 1000X magnification. 
Table 1. Effect of isoamyl alcohol on yeast morphology in YEPD medium

\begin{tabular}{ccc}
\hline Concentration of isoamyl & \multicolumn{2}{c}{ Yeast strain } \\
\cline { 2 - 3 } alcohol (\% v/v) & CCA 037* & CCA 567** \\
\hline 0 & 0 & 0 \\
0.1 & 0 & 0 \\
0.2 & 0 & 0 \\
0.3 & 7 & 4 \\
0.4 & 7 & 2 \\
0.5 & 14 & 3 \\
0.6 & 9 & 5 \\
0.7 & 2 & 6 \\
0.8 & 8 & 18 \\
0.9 & 8 & 8 \\
1.0 & NG & NG \\
\hline
\end{tabular}

Percentage of hyphal-like extensions $(*)$ or pseudohyphae $(* *)$ in the cultures (means of two separate experiments) NG, no growth

Around $18 \%$ of the cells were clumped in YEPD- $0.8 \%$ of IAA (Table 1). We have seen different responses to IAA depending on the strain. All of these morphology alterations were reversible to unicellular form when the yeast was reinoculated in YEPD alone.

Despite the troubles caused by treatment of sugar cane with glifosate in the fields, we did not observe any alteration in the yeast morphology when glifosate was added directly to the medium. However, indirect influences, like modification in the chemical composition of the sugar cane juice, cannot be put away.

When leucine was the sole nitrogen source, the yeasts produced large amounts of IAA $(3,13)$, and consequently, presented filamentous growth (3). We have not observed any yeast morphological changes when leucine was used as the sole nitrogen source in minimal medium. However, these changes may be dose-dependent, since we have used $0.1 \%$ and $0.01 \%$ instead of $2 \%$ (3).

Upon addition of IAA, a series of small, anucleate buds were produced in the first 8 hours. These buds are formed more rapidly than the cell doubling time. At later times rounds of nuclear division result in buds with a nucleus, while polarised growth results in the elongation of the buds. As a result, after 24 hours, chains of elongated cells are evident (9). Genetic experiments showed that this response to IAA depends upon the function of the Pho85, Swe1 and Mpk1 genes $(10,11)$.

The pseudohyphal pathway, induced by growth on nitrogen-limited medium, is well known and intensively studied $(3,8,12)$. This growth is sensed by two pathways that operate in parallel: one is based on a MAP kinase module, the other on cAMP and also throuh Ras2p. Both pathways converge to activate the transcription of the key genes required for filamentous response.
However, it was shown (3) that at a concentration of $0.5 \%$ $(\mathrm{v} / \mathrm{v})$ IAA induced the formation of hyphal-like extension in haploid and diploid strains of Sacch. cerevisiae in liquid complex medium. But at $0.25 \%(\mathrm{v} / \mathrm{v})$ IAA, these yeasts formed pseudohyphae. This alcohol also induced the formation of pseudohyphae in two species of Candida and both hyphallike extensions and pseudohyphae in Brettanomyces anomalus.

We have also observed hyphal-like extensions and formation of pseudohyphae in response to IAA for two industrial strains of yeasts from ethanolic fermentative processes. This work is the first to show the yeast morphology switch in response to 'fusel' alcohols in industrial yeast strains of this fermentation.

\section{ACKNOWLEDGMENTS}

The authors wish to thank CNPq/PIBIC for a grant to P.C.Silva and Departamento de Genética/ESALQ/USP for the use of the photomicroscope.

\section{RESUMO}

\section{Produção de pseudohifas e extensões semelhantes a hifas em linhagens industriais de leveduras induzida por álcool isoamílico}

As leveduras podem produzir pseudohifas e extensões semelhantes a hifas sob certas condições de crescimento, como a adição de álcool isoamílico. Esse álcool é o constituinte principal do óleo fusel, um subproduto da fermentação etanólica. A mudança de morfologia da levedura para a forma filamentosa pode causar problemas ao processo fermentativo. Neste trabalho, foi estudada a influência dos álcoois fusel (isoamílico e isopropílico), fontes de nitrogênio (sulfato de amônio e leucina) e glifosate (um maturador químico para cana-de-açúcar) adicionados a um meio complexo sobre linhagens industriais de leveduras isoladas do processo fermentativo. Duas linhagens industriais mostraram transição para pseudohifas (grupos de células) ou extensões semelhantes a hifas após adição de álcool isoamílico, de $0,3 \%$ a $0,9 \% \mathrm{v} / \mathrm{v}$. Todas as alterações foram reversíveis quando as leveduras foram reinoculadas em YEPD sem adição de álcool. Apesar das pseudohifas serem comumente resultantes de meios com limitação de nitrogênio, observou-se que esta morfologia resultou da adição de álcool isoamílico. Não foi detectada nenhuma influência da fonte de nitrogênio ou álcool isopropílico ou glifosate para quaisquer linhagens estudadas.

Palavras-chave: álcool isoamílico, etanol, levedura, pseudohifas, extensões semelhantes a hifas 


\section{REFERENCES}

1. Ceccato-Antonini, S.R.; Parazzi, C. Monitoramento microbiológico da fermentação etanólica: uma experiência. Jornal Cana, jan/2000, p. $25-26$.

2. Dickinson, J.R. 'Fusel' alcohols induce hyphal-like extensions and pseudohyphal formation in yeasts. Microbiology, 142: 1391-1397, 1996.

3. Gancedo, J.M. Control of pseudohyphae formation in Saccharomyces cerevisiae. FEMS Microbiol. Rev., 25: 107-123, 2001.

4. Gimeno, C.J.; Ljungdahl, P.O.; Styles, C.A.; Fink, G.R. Unipolar cell division in the yeast $S$. cerevisiae lead to filamentous growth: regulation by starvation and RAS. Cell., 68: 1077-1090, 1992.

5. ICIDCA. La industria de los derivados de la cana de azucar. Havana: ICIDCA, 1986, 576p.

6. Kron, S.J.; Styles, C.A.; Fink, G.R. Symmetric cell division in pseudohyphae of the yeast Saccharomyces cerevisiae. Mol. Biol. Cell., 5: 1003-1022, 1994.

7. Kuriyama, H.; Slaughter, J.C. Control of cell morphology of the yeast Saccharomyces cerevisiae by nutrient limitation in continuous culture. Lett. Appl. Microbiol., 20: 37-40, 1995.
8. Lengeler, K.B.; Davidson, R.C.; D’Souza, C.; Harashima, T.; Shen, W.C.; Wang, P.; Pan, X.W., Waugh, M.; Heitman, J. Signal transduction cascades regulating fungal development and virulence. Microbiol. Mol. Biol. Rev., 64: 746-750, 2000.

9. Lorenz, M.C.; Cutler, N.S.; Heitman, J. Characterization of alcoholinduced filamentous growth in Saccharomyces cerevisiae. Mol. Biol. Cell., 11: 183-199, 2000.

10. Nishizawa, M.; Kawasumi, M.; Fujino, M.; Toh-E, A. Phosphorilation of Sic1, a cyclin-dependent kinase (Cdk) inhibitor, by Cdk including Pho85 kinase is required for its prompt degradation. Mol. Biol. Cell., 9: 2393-2405, 1998.

11. Nugroho, T.T.; Aljumaily, W.; Mendenhall, M.D. Mutations on Cdc28 phosphorilation sites of Sic1, a yeast cyclin dependent kinase inhibitor, causes cell cycle arrest. Mol. Biol. Cell., 7: 149, 1996.

12. Pan, X.W.; Harashima, T.; Heitman, J. Signal transduction cascades regulating pseudohyphal differenciation of Saccharomyces cerevisiae. Curr. Opin. Microbiol., 3: 567-572, 2000.

13. Webb, A.D.; Ingraham, J.L. Fusel oil. Adv. Appl. Microbiol., 5: 317353, 1963.

14. Wright, R.M.; Repine, T.; Repine, J.E. Reversible pseudohyphal growth in haploid Saccharomyces cerevisiae is an aerobic process. Curr. Genet., 23: 388-391, 1993. 